\title{
Changes in DNA methylation patterns and repetitive sequences in blood lymphocytes of aged horses
}

\author{
Maciej Wnuk • Anna Lewinska • Artur Gurgul • Tomasz Zabek • \\ Leszek Potocki • Bernadetta Oklejewicz • Monika Bugno-Poniewierska • \\ Magdalena Wegrzyn • Ewa Slota
}

Received: 11 September 2012 / Accepted: 6 May 2013 / Published online: 23 May 2013

(C) The Author(s) 2013. This article is published with open access at Springerlink.com

\begin{abstract}
It is known that aged organisms have modified epigenomes. Epigenetic modifications, such as changes in global and locus-specific DNA methylation, and histone modifications are suspected to play an important role in cancer development and aging. In the present study, with the well-established horse aging model, we showed the global loss of DNA methylation
\end{abstract}

M. Wnuk $\cdot$ L. Potocki $\cdot$ B. Oklejewicz $\cdot$

M. Bugno-Poniewierska $\cdot$ M. Wegrzyn $\cdot$ E. Slota

Department of Genetics,

University of Rzeszów,

Rejtana 16C, PL 35-959, Rzeszów, Poland

M. Wnuk $(\triangle) \cdot$ A. Lewinska $\cdot$ L. Potocki $\cdot$ B. Oklejewicz

M. Bugno-Poniewierska $\cdot$ M. Wegrzyn $\cdot$ E. Slota

Centre of Applied Biotechnology and Basic Sciences,

University of Rzeszów,

Kolbuszowa, Rzeszów, Poland

e-mail:mawnuk@gmail.com

A. Lewinska

Department of Biochemistry and Cell Biology,

University of Rzeszów,

Rzeszów, Poland

A. Gurgul · T. Zabek · M. Bugno-Poniewierska Laboratory of Genomics,

National Research Institute of Animal Production,

Balice n. Cracow, Poland in blood lymphocytes during juvenile-to-aged period. Additionally, we tested a pattern of DNA methylation of ribosomal DNA and selected genes such as $I G F 2$ and found no significant changes during development and aging. We asked if genetic components such as polymorphisms within DNA methyltransferase genes, DNMT1, DNMT3a, and DNMT3b, may contribute to observed changes in global DNA methylation status. The analysis of seven intragenic polymorphisms did not reveal any significant association with changes in global DNA methylation. Telomere shortage and a loss of pericentromeric heterochromatin during juvenile-toaged period were also observed. Transcriptional rDNA activity, assessed as the number and size of nucleolar organizer regions, reflecting physiological state of the cell, and mitotic index were decreased with increasing horse donor age. Moreover, changes during juvenile-toaged period and adult-to-aged period were compared and discussed. Taken together, changes in global DNA methylation status originating in development and affecting the stability of repetitive sequences may be associated with previously reported genomic instability during horse aging.

Keywords Aging · Horse - Lymphocyte - DNA methylation $\cdot$ Repetitive sequences 


\section{Introduction}

Epigenetics, a heritable alteration in gene expression pattern without changes in gene sequence, plays a fundamental role in a plethora of cellular functions such as development, cell proliferation and differentiation, genetic imprinting, $\mathrm{X}$ chromosome inactivation, suppression of parasitic DNA and transcriptional noise, and maintenance of chromatin structure (Klein 2005; Richardson 2003). However, aberrant epigenetic signaling may lead to tumor progression, cellular senescence, and organism aging (Jones and Baylin 2002; Issa 2003; Wilson and Jones 1983). In mammals, the most relevant epigenetic events are DNA methylation and histone modifications such as methylation, acetylation, ubiquitination, and phophorylarion (Das and Singal 2004; Jenuwein and Allis 2001). DNA methylation involves an addition of a methyl group to the 5-position of the cytosine pyrimidine ring to form 5methyl-2'-deoxycytidine (5-mdC) (Das and Singal 2004), which is catalyzed by DNA methyltransferases (DNMTs) such as DNMT1, DNMT3a, and DNMT3b (Robertson 2002). DNMT1 activity is responsible for restoring established methylation patterns during DNA replication, while DNMT3a and DNMT3b are involved in de novo methylation resulting in methylation on previously unmethylated DNA (Bestor et al. 1988; Okano et al. 1998).

Global DNA methylation status has been shown repeatedly as genomic 5-mdC content is decreased with age in different tissue samples and cell lines (animal and human) (Wilson et al. 1987; Romanov and Vanyushin 1981; Rath and Kanungo 1989; Mays-Hoopes et al. 1986; Wilson and Jones 1983; Fuke et al. 2004; Johnson et al. 2012). The exact mechanisms underlying age-dependent global DNA hypomethylation are largely unknown. Nevertheless, it is postulated that decreased DNMT activity may be a determinant of the loss of global DNA methylation during aging (Richardson 2003). It was shown that in stimulated human $\mathrm{T}$ lymphocytes, DNMT1 mRNA and protein levels dropped fourfold from birth to middle age, while DNMT3a protein levels decreased throughout life (Zhang et al. 2002). Moreover, genomic DNA hypomethylation is believed to be a result of demethylation in repeated DNA sequences such as pericentromeric repeats and parasitic elements which was especially seen for Alu elements during aging (Bollati et al. 2009).
On the other hand, locus-specific DNA hypermethylation was recorded during aging (Issa 2003; Johnson et al. 2012). An increase in 5-mdC level within rDNA from aged rat liver was reported (Oakes et al. 2003). Age-related increase in promoter methylation, mainly $\mathrm{CpG}$ islands, was also found in many genes, e.g., encoding E-cadherin, c-fos, collagen $\alpha 1(\mathrm{I})$, and tumor suppressor genes such as lysyl oxidase, p16INK2a, runt-related transcription factor 3, or TPA-inducible gene 1 (So et al. 2006; Bornman et al. 2001; Choi et al. 1996; Takatsu et al. 1999). Taken together, global DNA hypomethylation may stimulate expression of proto-oncogenes and cause chromosomal translocations and mutations, while loci-specific DNA hypermethylation may suppress the expression of tumor suppressor genes which in turn may contribute to both cancer progression and aging.

Since horse is a quite long-lived animal with a mean and maximum lifespan of 25 and 40 years, respectively (McFarlane et al. 2001), and similar to old people, old horses suffered from age-related diseases such as cancer (Paradis 2002), a horse aging model was suggested (Adams et al. 2008). With the horse aging model, the mechanisms of immunosenescence and inflammaging were intensively studied (Adams et al. 2008, 2009; Horohov et al. 1999, 2002; McFarlane et al. 2001). Moreover, telomeres were found to be implicated in the aging of equine cells both in vivo and in vitro since horse lymphocytes exhibited an age-dependent loss of telomeres and telomere length and immunosenescence were correlated with horse age (Argyle et al. 2003; Katepalli et al. 2008). More recently, our investigations showed that breed-independent and age-associated changes in genomic stability may contribute to horse aging (Wnuk et al. 2011).

To our knowledge, no global DNA methylation pattern was studied thus far to elucidate correlations between changes in DNA methylation status in the horse genome and horse donor age neither in vivo nor in vitro. The aims of this study were to examine development- and age-associated changes in global DNA methylation and selected sequences/regions such as rDNA or IGF2 promoter gene in blood lymphocytes of aged horses and to determine the impact of different polymorphisms within DNMT genes on obtained results. Changes in repetitive sequences such as telomeres and pericentromeric heterochromatin were also monitored during both juvenile-to-aged period and adult-to-aged period. 


\section{Materials and methods}

Chemicals

Giemsa stain solution was from Fluka (Buchs, Switzerland), phosphate-buffered saline (PBS) was from Gibco (Gibco, Invitrogen Corporation, Grand Island, NY, USA), and DAPI II Counterstain was from Abbott Molecular (IL, USA). All other reagents, if not mentioned otherwise, were purchased from Sigma (Steinheim, Germany) and were of analytical grade.

Blood collection and cell culture

In general, the blood samples were taken from 60 horses (30 of Hucul horse breed and 30 of Anglo-Arabian horse breed). The animals were 4 days to 21 years old. Additionally, for DNA methylation analysis, an enriched 75 horse group with additional mature horses, 4 to 7 years old, $n=15$, was used. The study was approved by the Second Local Ethical Commission in Cracow.

For AgNOR analysis and rDNA methylation, the lymphocytes were cultured in RPMI 1640 medium with L-glutamine, $\mathrm{HCO}_{3}{ }^{-}$, and phenol red, containing $10 \%(v / v)$ fetal calf serum (Biomed, Lublin, Poland), penicillin $\mathrm{G}$ potassium salt $(100 \mathrm{U} / \mathrm{ml})$ (Sigma, Deisenhofen Germany), streptomycin sulfate salt (100 $\mu \mathrm{g} / \mathrm{ml})$ (Sigma, Deisenhofen, Germany), and pokeweed mitogen $(5 \mu \mathrm{g} / \mathrm{ml})$ (Sigma, St. Louis, USA) and incubated at $37^{\circ} \mathrm{C}$ for $72 \mathrm{~h}$.

\section{Global DNA methylation}

DNA methylation was estimated as a 5-mdC level with high-performance liquid chromatography (HPLC). Using HPLC, in equine DNA hydrolysates from whole blood samples, 5-mdC and 2'-deoxycytidine (dC) were determined with a UV detector. Separation of the $2^{\prime}-$ deoxyribonucleosides was performed with $250 \times$ $4.6 \mathrm{~mm} \mathrm{5u}$ Hypersil GOLD Column equipped with $10 \times 4 \mathrm{~mm} 5 \mathrm{u}$ Hypersil GOLD drop in guards precolumn. The nucleosides were eluted with $5 \%$ methanol using a HPLC grade mixture of methanol/water (20:80\%) $(v / v)$ with sodium phosphate monobasic and a flow rate of $1 \mathrm{ml} / \mathrm{min}$. The injection volume of the sample was $20 \mu \mathrm{l}$. The eluate was monitored with a UV detector at $279 \mathrm{~nm}$ (5-mdC detection) and $271 \mathrm{~nm}$ (dC detection). Linear calibration curves were obtained in the concentrations ranging from $2.5 \mathrm{nmol} / 20 \mu \mathrm{l}$ to $20 \mathrm{nmol} / 20 \mu \mathrm{l}$ for $\mathrm{dC}$ and from $0.25 \mathrm{nmol} / 20 \mu \mathrm{l}$ to $2 \mathrm{nmol} / 20 \mu \mathrm{l}$ for 5 -mdC. The 5 $\mathrm{mdC}$ content in genomic DNA was expressed as a ratio of 5-mdC/(dC+5-mdC) [percent]. Acquisition and quantitative analyses of the chromatograms were carried out using Chromeleon 4.3 software (Dionex Corporation).

rDNA methylation

To visualize nucleolar rDNA methylation, a combination of primed in situ DNA synthesis (PRINS) technique and 5-mdC immunostaining was used.

For 5-mdC immunostaining, lymphocytes were fixed with $4 \% p$-formaldehyde (at room temperature for $1 \mathrm{~h}$ ) and permeabilized with $0.1 \%$ Triton X-100 in $0.1 \%$ sodium citrate dihydrate (at $4{ }^{\circ} \mathrm{C}$ for $2 \mathrm{~min}$ ). Then, the cells were applied onto the slides, which were dried and incubated with $1 \%$ bovine serum albumin (BSA) in PBS at $37{ }^{\circ} \mathrm{C}$ for $30 \mathrm{~min}$. After washing with PBST (PBS supplemented with $0.25 \%$ Triton X-100), the slides were incubated with mouse monoclonal antibody against 5-mdC (Abcam, Cambridge, UK) (diluted 1:200 in 1\% BSA in PBST) at room temperature for $2 \mathrm{~h}$ and with a Cy5-conjugated, secondary polyclonal antibody goat against mouse IgG (Abcam, Cambridge, UK) (diluted 1:500 in 1\% BSA 1 in PBST) at room temperature for $1 \mathrm{~h}$.

For PRINS, fixed nuclei were treated with $100 \mu \mathrm{g} / \mathrm{ml}$ RNase in $2 \times$ saline sodium citrate (SSC) buffer in a humidified chamber at $37{ }^{\circ} \mathrm{C}$ for $1 \mathrm{~h}$ for better results. After RNase, slides were washed three times with $2 \times$ SSC and then were treated with $0.01 \%$ pepsin in $10 \mathrm{mM}$ $\mathrm{HCl}$ at $37{ }^{\circ} \mathrm{C}$ for $30 \mathrm{~min}$. The slides were then washed twice with PBS (pH 7.4) and once with PBS with $50 \mathrm{mM}$ $\mathrm{MgCl}_{2}$ and passed through the set of ethanol solutions (70, 80, and $95 \%$ ). The primers were designed according to the NCBI base. We used specific primers for the mammalian 18S rDNA (Operon, USA) which are as follows: Fwd 5'-CCACGCTCTCGCCAACGTTAAT-3' and Rev 5'-CGCTGTCCCACCGTCTCCTA-3'.

Primers designed for mammalian-specific $18 \mathrm{~S}$ rDNA sequences were applied to identify equinespecific $18 \mathrm{~S}$ rDNA sequences according to sequence homology. The PRINS reaction mixture in a total volume of $25 \mu \mathrm{l}$ per slide contained $0.5 \mathrm{mM}$ dATP, $\mathrm{dCTP}$, and dGTP; $0.025 \mathrm{mM}$ dTTP; $1 \mathrm{nM}$ biotindUTP; 2 U AmpliTaqGOLD polymerase (Invitrogen, Germany); $1 \times$ Taq polymerase buffer; $2.5 \mathrm{mM} \mathrm{MgCl}_{2}$, $4 \mathrm{mM}$ Fwd primer, and $4 \mathrm{mM}$ Rev primer; $5 \%$ glycerol; and sterile distilled water (milliQ). The PRINS 
reaction mixture was applied on the slide covered with a coverslip and sealed with fixogum to prevent evaporation. Denaturation temperature, duration time/annealing and prolongation temperature, and duration time were $94{ }^{\circ} \mathrm{C}, 5 \mathrm{~min} / 61{ }^{\circ} \mathrm{C}$, and $30 \mathrm{~min}$, respectively.

The PRINS reaction was stopped by transferring the slides to a stop buffer containing $50 \mathrm{mM} \mathrm{NaCl}$ and $50 \mathrm{mM}$ EDTA (pH 8.0) at $58{ }^{\circ} \mathrm{C}$ for 5 min and next to the stop buffer at room temperature for $7 \mathrm{~min}$. Next, the slides were washed twice with $2 \times \mathrm{SSC}$ at room temperature for $5 \mathrm{~min}$. Before detection, the slides were dehydrated with the set of ethanol solutions (70, 80, and $95 \%$ ). Detection of biotindUTP was performed according to a standard procedure (http://www.cambio.co.uk) with Star*FISH ${ }^{\odot}$ biotin detection kit containing avidin-FITC (Cambio, UK).

The slides were counterstained with a drop of the mounting medium with DAPI II counterstain and digital cell images were captured with an Olympus BX61 fluorescence microscope equipped with a DP72 CCD camera and Olympus CellF software. To analyze nucleolar 5mdC content, ImageJ software (http://rsbweb.nih.gov/ij/) was used. The integrated fluorescence density is presented as relative units.
Methylation of $\mathrm{CpG}$ islands in the promoter of IGF2 gene

DNA from whole blood samples was isolated with Wizard Genomic DNA Purification Kit (Promega, Germany) and modified with sodium bisulfite with methylSEQr ${ }^{\mathrm{TM}}$ Bisulfite Conversion Kit (Applied Biosystems, CA, USA). One single genomic region of equine $I G F 2$ putative promoter sequence (NC_009155.2: 30636212, 30636931) was determined through MatInspector software (Cartharius et al. 2005) spanning 720 bp from -509 to +211 relative to the transcription start site of IGF2 mRNA transcript (NM_001114539) annotated in reverse orientation. No other $\mathrm{CpG}$ islands were included in the investigation. Selected sequence was used for the construction of the BSPCR assay. For BSPCR, primers were designed using Methyl Primer Express $^{\circledR}$ Software v1.0 (Table 1). The BSPCR reaction mixture contained $10 \mathrm{ng}$ template, $1 \times$ PCR buffer (Tris$\left.\mathrm{HCl}, \mathrm{KCl},\left(\mathrm{NH}_{4}\right)_{2} \mathrm{SO}_{4}, \mathrm{pH} 8.7\right), 2 \mathrm{mM} \mathrm{MgCl} 2,0.2 \mathrm{mM}$ dNTP (Applied Biosystems, CA, USA), $0.125 \mu \mathrm{M}$

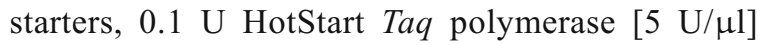
(Qiagen, Germany), and milliQ water to a final volume
Table 1 Primers used for amplification and sequencing of predicted equine $I G F 2$ promoter region

\begin{tabular}{|c|c|c|}
\hline BSPCR product & Primer name & Sequence $\left(5^{\prime}-3^{\prime}\right)$ \\
\hline \multirow[t]{2}{*}{1} & F: IGF2_ABH & GGAGGTTTTGTATAGGTGTTTG \\
\hline & R: IGF2_A & AAACCСCССТАCТCAACTAA \\
\hline \multirow[t]{2}{*}{2} & F: IGF2_ABH & GGAGGTTTTGTATAGGTGTTTG \\
\hline & R: IGF2_BC & СССТАСТСААСТААТССТСААА \\
\hline \multirow[t]{2}{*}{3} & F: IGF2_CG & GGTTTTGTATAGGTGTTTGAGG \\
\hline & R: IGF2_BC & СССТАСТСААСТААТССТСАAА \\
\hline \multirow[t]{2}{*}{4} & F: IGF2_D & TTTGTATAGGTGTTTGAGGAAGG \\
\hline & R: IGF2_DEF & AAACCCCСCTACTCAACTAATC \\
\hline \multirow[t]{2}{*}{5} & F: IGF2_E & GGAGGTTTTGTATAGGTGTTTGA \\
\hline & R: IGF2_DEF & AAACCCCСCTACTCAACTAATC \\
\hline \multirow[t]{2}{*}{6} & F: IGF2_F & GGTTTTGTATAGGTGTTTGAGGA \\
\hline & R: IGF2_DEF & AAACСССССТАСТСАACTAАТC \\
\hline \multirow[t]{2}{*}{7} & F: IGF2_CG & GGTTTTGTATAGGTGTTTGAGG \\
\hline & R: IGF2_GH & АААССССССТАСТСААСТААТ \\
\hline \multirow[t]{2}{*}{8} & F: IGF2_ABH & GGAGGTTTTGTATAGGTGTTTG \\
\hline & R: IGF2_GH & AAАCСССССТАСТСААСТАAТ \\
\hline \multirow[t]{2}{*}{9} & F: IGF2_IJ & GTTAGGTGTTTTGGAGGTTTTG \\
\hline & R: IGF2_I & ССССССТАСТСААСТААТСС \\
\hline \multirow[t]{2}{*}{10} & F: IGF2_IJ & GTTAGGTGTTTTGGAGGTTTTG \\
\hline & R: IGF2_J & ССТАААССССССТАСТСААС \\
\hline
\end{tabular}


of $20 \mu \mathrm{l}$. BSPCR reaction was performed in the following conditions: initial denaturation at $95^{\circ} \mathrm{C}$ for $15 \mathrm{~min}, 5 \mathrm{cy}-$ cles of denaturation at $97{ }^{\circ} \mathrm{C}$ for $5 \mathrm{~s}$, annealing at $62{ }^{\circ} \mathrm{C}$ for $2 \mathrm{~min}$, elongation at $72{ }^{\circ} \mathrm{C}$ for $45 \mathrm{~s}, 35$ cycles of denaturation at $97{ }^{\circ} \mathrm{C}$ for $5 \mathrm{~s}$, annealing at $60{ }^{\circ} \mathrm{C}$ for 2 min, elongation at $72{ }^{\circ} \mathrm{C}$ for $45 \mathrm{~s}$, and final elongation at $72{ }^{\circ} \mathrm{C}$ for $7 \mathrm{~min}$. The BSPCR products were digested with enzyme solution mix (U/ $\mu \mathrm{L} \mathrm{SAP}$ and $20 \mathrm{U} / \mu \mathrm{l}$ ExoI) and incubated at $37{ }^{\circ} \mathrm{C}$ for $30 \mathrm{~min}$ followed by heat inactivation at $80{ }^{\circ} \mathrm{C}$ for $15 \mathrm{~min}$. Subsequently, the BSPCR products were sequenced from both complementary strands with the use of BigDye ${ }^{\circledR}$ Terminator v3.1 Cycle Sequencing Kit. Sequencing products were purified using BigDye ${ }^{\circledR}$ XTerminator Purification Kit according to the manufacturer's instructions and separated in the presence of polymer POP-7 using Genetic Analyzer ABI3130xl (Applied Biosystems, CA, USA). The sequences were verified with the use of sequencing analysis (Applied Biosystems, CA, USA) and FinchTV (http:// www.geospiza.com/finchtv). Forward and reverse DNA strand sequences were aligned using GeneDoc Multiple Sequence Alignment Editor (Nicholas et al. 1997). The presence of methylated cytosines was analyzed and the DNA methylation profile was shown as a lollipop diagram (CpG viewer application) (Carr et al. 2007).

\section{DNMT1 polymorphism detection and genotyping}

Polymorphisms in selected regions of DNMT1 gene (exon 3 and exons 22-23 and 37-38) were identified and genotyped by direct re-sequencing. Studied regions were amplified with Fast Cycling PCR Kit (Qiagen, Germany). The DNMT1 gene fragment spanning exon 3 was amplified using standard reaction mixture recommended by the manufacturer. Both remaining fragments were amplified with the addition of $5 \times \mathrm{Q}$ solution as specified in the manufacturer's protocol. The PCR primers used are given in Table 2. The PCR conditions were as follows (annealing temperature of each primer pair is specified in Table 2): initial activation at $95{ }^{\circ} \mathrm{C}$ for $7 \mathrm{~min}, 35$ cycles of denaturation at $95{ }^{\circ} \mathrm{C}$ for $5 \mathrm{~s}$, annealing for $5 \mathrm{~s}$, extension at $68^{\circ} \mathrm{C}$ for $30 \mathrm{~s}$, and final extension at $72{ }^{\circ} \mathrm{C}$ for $1 \mathrm{~min}$. After amplification, PCR products were cleaned up with ExoSAP-IT enzymatic mixture (USB Corporation) and sequenced from both complementary strands with the use of BigDye ${ }^{\circledR}$ Terminator v3.1 Cycle Sequencing Kit. Sequencing products were purified using BigDye ${ }^{\circledR}$ XTerminator Purification Kit. Capillary electrophoresis was performed in 3130xl Genetic Analyzer (Life Technologies).

DNMT3a and DNMT3b polymorphism selection and SNaPshot Multiplex genotyping

Since no exonic polymorphisms were reported in dbSNP in DNMT3a and DNMT3b genes, we decided to test four known intronic polymorphisms for association with global DNA methylation. Three dbSNP polymorphisms located in different regions of the DNMT3a gene were tested. Polymorphism was selected to span the whole gene ranging from intron 3, through intron 7 to intron 17 (rs69099453, rs68974352, rs68974357). In DNMT3b gene, one of the two known polymorphisms (rs69265247), localized in intron 13, was genotyped.

The polymorphisms studied in DNMT3a and DNMT3b genes were genotyped using ABI PRISM SNaPshot Multiplex Kit (Life Technologies). The assay is based on single-base extension (SBE) reaction, performed with single nucleotide polymorphism (SNP)-specific primers/probes and fluorescentlabeled ddNTPs on PCR pre-amplified template.

The DNA fragments spanning studied polymorphisms were co-amplified in multiplex PCR reaction using Type-it Mutation Detect PCR Kit (Qiagen,

Table 2 PCR primers and annealing temperature used for amplification of selected regions of DNMT1 gene

\begin{tabular}{|c|c|c|c|c|c|}
\hline \multirow{3}{*}{$\begin{array}{l}\text { Gene } \\
\text { DNMT1 }\end{array}$} & \multirow{3}{*}{$\begin{array}{l}\text { Region } \\
\text { Exon } 3\end{array}$} & \multicolumn{2}{|c|}{ PCR primers } & \multirow{3}{*}{$\begin{array}{l}\text { PCR product size }[\mathrm{bp}] \\
821\end{array}$} & \multirow{3}{*}{$\frac{\text { Annealing temperature }\left[{ }^{\circ} \mathrm{C}\right]}{58}$} \\
\hline & & $\mathrm{F}$ & CAAAGTTGCTTAACGAGTGTTTTT & & \\
\hline & & $\mathrm{R}$ & TAACGCTATCAAGTAACGGGAGA & & \\
\hline & \multirow[t]{2}{*}{ Exons $22-23$} & F & AAAAGAGGAAGATTGGCAACAG & \multirow[t]{2}{*}{672} & \multirow[t]{2}{*}{60} \\
\hline & & $\mathrm{R}$ & CTGCTCGAGAAAGGGTCTGG & & \\
\hline & \multirow[t]{2}{*}{ Exons $37-38$} & $\mathrm{~F}$ & GTAGACAGTGTTAAGCGGCAAAAG & \multirow[t]{2}{*}{698} & \multirow[t]{2}{*}{60} \\
\hline & & $\mathrm{R}$ & ATGCCCACCTGGTCAGAG & & \\
\hline
\end{tabular}


Germany). The reaction mixture contained $1 \times$ Master Mix, $1.25 \mu \mathrm{M}$ of each primer, $50 \mathrm{ng}$ of genomic DNA, and PCR-grade water to a final volume of $25 \mu \mathrm{l}$. The following PCR conditions were used: initial activation at $95{ }^{\circ} \mathrm{C}$ for $5 \mathrm{~min}, 30$ cycles of denaturation at $95{ }^{\circ} \mathrm{C}$ for $30 \mathrm{~s}, 90 \mathrm{~s}$ of annealing at $60^{\circ} \mathrm{C}, 25 \mathrm{~s}$ of extension at $72{ }^{\circ} \mathrm{C}$, and final extension at $68^{\circ} \mathrm{C}$ for $15 \mathrm{~min}$. PCR products were checked for relative yield and purity on agarose gel and purified with ExoSAP-IT PCR Cleanup Kit (USB Corporation). The SBE reaction was performed in standard conditions, according to the manufacturer's protocol. Products of the SBE reaction were analyzed using 3130xl Genetic Analyzer (Life Technologies) and GeneMapper software. All PCR and SBE primers used are shown in Table 3.

Telomere restriction fragment (TRF) length (Southern blot analysis)

DNA samples were extracted from equine lymphocytes by the Genomic DNA purification kit (Gentra Puregene Blood Kit, Qiagen) according to the manufacturer's instructions. Mean TRF length was measured using the TeloTAGGG telomere length assay kit (Roche Molecular Biochemical, Indianapolis, USA) according to the manufacturer's instructions. Briefly, purified DNA $(1.5 \mu \mathrm{g})$ was digested with $H i n \mathrm{fI} / R s a \mathrm{I}$ mixture $(10 \mathrm{U} / \mu \mathrm{g}$ DNA), separated by $0.8 \%$ agarose gel electrophoresis in Tris-acetate-EDTA buffer, and transferred onto a nylon membrane (Roche) by capillary transfer. Then, the membrane was hybridized to a digoxigenin (DIG)-labeled telomere-specific probe, and telomeres were detected with an alkaline phosphatase-conjugated anti-DIG antibody. The chemiluminescence signal was detected with substrate for alkaline phosphatase (CDP-Star) and the G: BOX imaging system (Syngene, Cambridge, UK). Mean TRF length was calculated using the formula: $\mathrm{L}=\Sigma(\mathrm{OD} 1 \mathrm{~L} 1) / \Sigma(\mathrm{OD} 1)$, where OD1 is the signal intensity at position 1 and L1 is the length of the DNA (bp) at position 1. The OD1 and L1 were estimated using ImageJ software (http://rsbweb.nih.gov/ij/).

Pericentromeric heterochromatin: C-banding (CBG)

Metaphase spreads were obtained from routine 72-h lymphocyte cultures with colchicine $(1 \mu \mathrm{g} / \mathrm{ml})$ (Sigma, St. Louis, USA), followed by a 10-min treatment with $75 \mathrm{mM} \mathrm{KCl}$ at $37^{\circ} \mathrm{C}$ and fixation in methanol/glacial acetic acid (3:1). C-banding was performed according to 
Sumner (1972), and the lymphocyte slides were incubated with $0.2 \mathrm{M} \mathrm{HCl}$ for $30 \mathrm{~min}$, then washed in $\mathrm{H}_{2} \mathrm{O}$, and treated with a saturated solution of $\mathrm{Ba}(\mathrm{OH})_{2}$ (Sigma, St. Louis, USA) at $50{ }^{\circ} \mathrm{C}$ for $10 \mathrm{~min}$. After washing in $\mathrm{H}_{2} \mathrm{O}$, slides were incubated in $2 \times \mathrm{SSC}$ at $61{ }^{\circ} \mathrm{C}$ for $1 \mathrm{~h}$ and stained with Giemsa (5\% in Sorensen buffer). The mean size of pericentromeric heterochromatin blocks were estimated by morphometric method with ImageJ software (http://rsbweb.nih.gov/ij/).

Proliferation: mitotic index and AgNOR assay

\section{Mitotic index}

Metaphase spreads were obtained from routine 72-h lymphocyte cultures with colchicine $(1 \mu \mathrm{g} / \mathrm{ml})$ (Sigma, St. Louis, USA), followed by a 10-min treatment with $75 \mathrm{mM} \mathrm{KCl}$ at $37^{\circ} \mathrm{C}$ and fixation in methanol/glacial acetic acid (3:1). The slides were treated with $0.1 \mathrm{mg} / \mathrm{ml}$ trypsin and stained with Giemsa (5\% in Sorensen buffer). A total of 100 good quality cells, from each of the three independent cultures used, were observed with a light microscope and metaphase spreads were scored (metaphase spreads per 100 cells [percent]).

\section{Silver staining of nucleolar organizer regions (AgNOR): argyrophilic proteins visualization}

To characterize cell proliferative activity during horse aging, silver staining of nucleolar proteins was performed. Since a positive correlation between interphase AgNORs and cell proliferation rate is well established, the AgNOR method can be used to estimate cell kinetics (Derenzini et al. 2000).

Silver staining was performed according to Howell and Black (1980), by incubation of the lymphocyte slides with a colloidal developer containing $50 \%$ $\mathrm{AgNO}_{3}$ (Sigma, St. Louis, USA) in the dark at $37{ }^{\circ} \mathrm{C}$ for $15 \mathrm{~min}$. After washing in tap water, the preparations were stained with $5 \%$ Giemsa for $10 \mathrm{~s}$.

\section{AgNOR analysis}

The analysis of interphase AgNORs of 100 lymphocytes was conducted with the counting and morphometric methods according to Derenzini and Trere (1991) and the guidelines of the Committee on AgNOR Quantification (Aubele et al. 1994) using an Olympus CellF software. We measured the area occupied by AgNOR proteins exclusively in the lymphocytes that contained only one AgNOR dot. Interphase NOR activity was expressed as total size and number of silver deposit areas which reflects cellular rDNA transcriptional activity and is related to cell proliferation activity (Derenzini et al. 2000; Schmiady et al. 1979).

\section{Statistical analysis}

The results represent the mean \pm SD from at least three independent experiments of samples collected from 60 animals (to analyze DNA methylation, 75 animals were used). All microscopic evaluations were done on randomized and coded slides. Differences in genomic 5methyl-2'-deoxycytidine content in different genotype groups were assessed with one-way analysis of variance (ANOVA) with post hoc testing using Tukey's multiple comparison test. A $p$ value of less than 0.05 was considered significant. Correlation analysis of the data was performed using linear correlation (Pearson $r$ ) test. All statistical analyses were done using StatSoft, Inc. (2005), STATISTICA, version 7.0 (www.statsoft.com).

\section{Results}

In general, we used blood from 60 healthy horses, aged from 4 days to 21 years (mean $\pm \mathrm{SD}, 7.8 \pm 8.4$ years), to study age-associated changes in DNA methylation levels and repetitive sequences. To exclude some breeddependent phenomena, we used 30 horse donors from Hucul breed (mean $\pm \mathrm{SD}, 8.1 \pm 9.1$ years) and 30 horse donors from Anglo-Arabian breed (mean \pm SD, $7.6 \pm$ 7.8 years) and conducted all analysis in each breed group and in the combined group. For DNA methylation analysis, both global and rDNA methylation, enriched 75 horse group with additional mature horses, 4 to 7 years old, $n=15$, was used. To discriminate between developmental and age-associated changes, we performed two different regression analyses and then compared them (juvenile-to-aged period versus adult-to-aged period).

In the combined groups $(n=60$ and $n=75$ with additional mature horses, 4 to 7 years old, $n=15$ ), we recorded a statistically significant decrease in global DNA methylation level (the relative genomic 5methyl-2'-deoxycytidine, 5-mdC, content [percent]) during juvenile-to-aged period, $r=-0.26, p=0.045$ and $r=-0.24, p=0.038$ (Fig. 1a, b). Then, we estimated how DNA methylation results obtained from very 

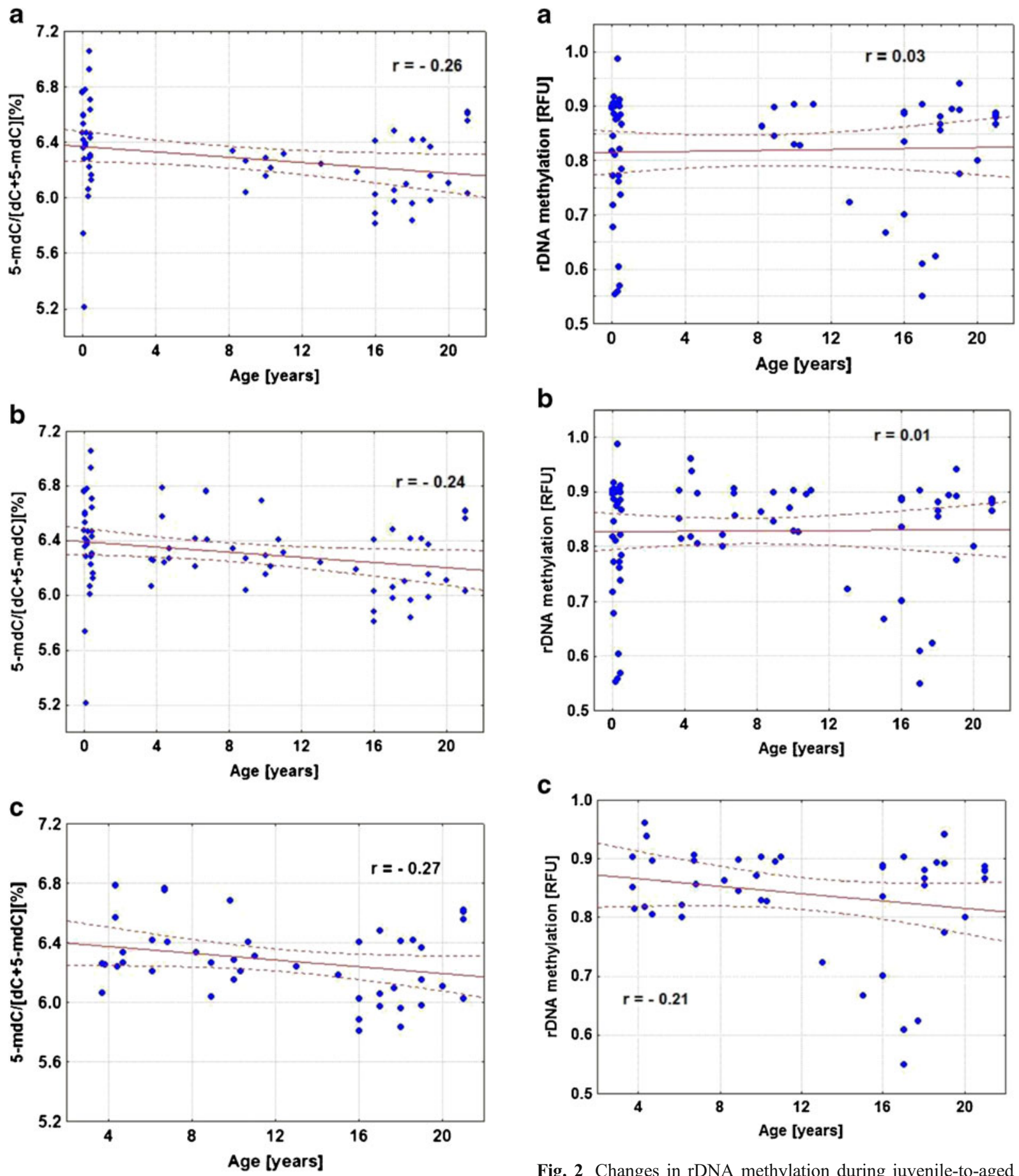

Fig. 1 Changes in global 5-methyl-2'-deoxycytidine level during juvenile-to-aged period (a, b) and adult-to-aged period (c). Correlation analysis within the combined horse group (Hucul and AngloArabian breed) is shown. a $n=60, r=-0.26, p=0.045$; $\mathbf{b} n=75, r=$ $-0.24, p=0.038$; c $n=44, r=-0.27, p=0.072$. Results represent the mean from three independent experiments. Correlation analysis of the data was performed using a linear correlation (Pearson $r$ ) test

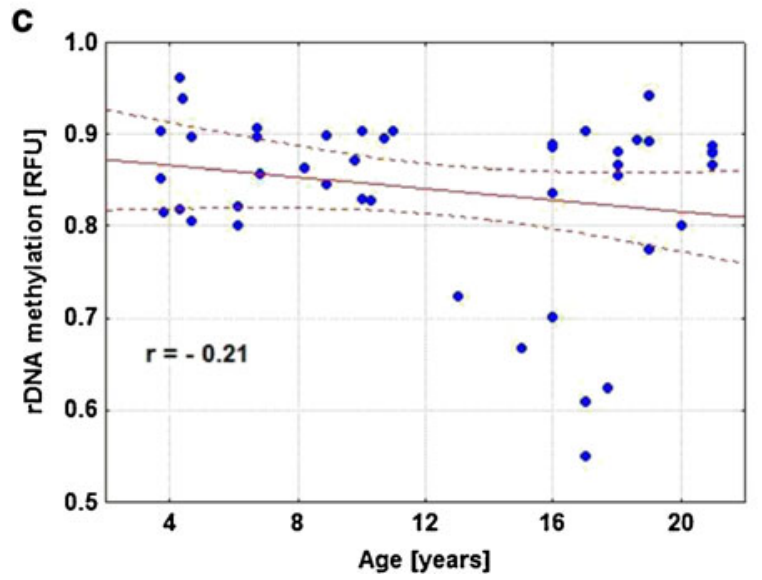

Fig. 2 Changes in rDNA methylation during juvenile-to-aged period (a, b) and adult-to-aged period (c). Correlation analysis within the combined horse group (Hucul and Anglo-Arabian breed) is shown. a $n=60, r=0.03, p=0.795$; b $n=75, r=0.01$, $p=0.917$; c $n=44, r=-0.21, p=0.171$. Results represent the mean from three independent experiments. Correlation analysis of the data was performed using a linear correlation (Pearson $r$ ) test 
young horses contribute to observed loss of DNA methylation during horse aging excluding very young horse samples from the analysis (Fig. 1c). We were still able to observe a negative correlation between global DNA methylation and horse donor age, $r=-0.27$ (Fig. 1c), compared to the juvenile-to-aged period (Fig. 1a, b). Nevertheless, due to a lower number of samples after data exclusion (Fig. 1c), the effect was not statistically significant $(n=44, p=0.072)$.

We also checked the rDNA methylation pattern of specific repetitive sequences such as $5.8 \mathrm{~S}, 18 \mathrm{~S}$, and $28 \mathrm{~S}$ rDNA. We were unable to demonstrate any evident correlation between rDNA methylation and horse donor age (Fig. 2).

A mild positive correlation between rDNA methylation and horse donor age was observed during the juvenile-to-aged period, both $n=60$ and $n=75, r=0.03$ and $r=0.01$, respectively (Fig. $2 \mathrm{a}, \mathrm{b}$ ), while during the adult-to-aged period, a negative correlation was recorded, $r=-0.21$ (Fig. 2c). Nevertheless, none of the observed effects were of statistical significance.

Since the global DNA hypomethylation with a concomitant promoter hypermethylation is considered as a hallmark of age-related epigenetic changes (Wilson et al. 1987; Fuke et al. 2004; Agrawal et al. 2010), we decided to check the methylation status of $\mathrm{CpG}$ islands in the promoter of $I G F 2$ gene. A fragment of $720 \mathrm{bp}$ of contig NC_009155 of chromosome ECA 12 (start: 30636212; stop: 30636931) was found to be the predicted promoter region of $I G F 2$ gene. Ten primer pairs were used to determine the conditions of amplification of equine bisulfite-modified DNA (Table 1).

Subsequently, the use of the most designed primers allows to obtain BSPCR products in the expected range of size (Fig. 3a). Due to the occurrence of $\mathrm{T}$ and $\mathrm{G}$ homopolymer stretches after bisulfite conversion of DNA, several BSPCR primer pairs were tested for sequencing and one of them was successfully used to investigate the methylation state on three $\mathrm{CpG}$ sites of $I G F 2$ gene of 60 horses (Fig. 3b). Methylation analysis of selected $\mathrm{CpG}$ islands in the promoter of IGF2 gene indicated the presence of cytosine peaks within the $\mathrm{CpG}$ sites of bisulfite-converted DNA which provides evidence on the predominant methylation state of the investigated DNA fragment (Fig. 3c, blue and d, filled beads). Small thymine peaks accompanying main cytosine peaks suggested also the presence of a small number of unmethylated cytosines compared to methylated ones (Fig. 3c, red). A summary of the methylation pattern within the three selected $\mathrm{CpG}$ sites of $I G F 2$ gene involving the total horse group is shown in Fig. 3d (lollipop diagram, filled beads).

Subsequently, we asked if polymorphisms within DNA methyltransferase genes (DNMT1, DNMT3a, and $D N M T 3 b$ ) may be associated with the observed changes in global DNA methylation status. All PCR and SBE primers used are listed in Tables 2 and 3.

Since no polymorphism in the region of the putative DNMT1 horse gene was reported, we sequenced three selected regions of the gene to identify potential nucleotide variations. The regions spanned different parts of the gene (exon 3 and exons 22-23 and 37-38) and covered sequences encoding fragments of different functionally important domains of DNMT1 protein such as DMAP1-binding domain, zinc finger domain (zf-CXXC), and DNA binding sites. We found three intronic polymorphisms located in introns: $2(\mathrm{C} \rightarrow \mathrm{T})$, $21(\mathrm{~A} \rightarrow \mathrm{G})$, and $22(\mathrm{~A} \rightarrow \mathrm{G})$ (GenBank accession numbers: JN225421, JN225422). No polymorphisms were detected in the region of exons 37 and 38 (JN225420). Since no exonic polymorphisms were reported in $\mathrm{dbSNP}$ in DNMT3 $a$ and DNMT3b genes, we decided to test four known intronic polymorphisms for association with global DNA methylation. Within DMNT3a gene, three known SNP were analyzed $(\mathrm{A} \rightarrow \mathrm{G}$, in intron 3 , dbSNP number rs69099453; $\rightarrow \mathrm{G}$, in intron 7, dbSNP number rs68974352; $\mathrm{C} \rightarrow \mathrm{G}$, in intron 17 , dbSNP number rs68974357). Within DMNT3b gene, one known SNP was studied $(\mathrm{C} \rightarrow \mathrm{T}$, in intron 13 , dbSNP number rs69265247). The allele and genotype frequencies of the seven analyzed SNP of DNA methyltransferase genes (DNMT1, DNMT3a, and DNMT3b) in the total horse group are shown in Table 4. All studied polymorphisms were in Hardy-Weinberg equilibrium $(p>0.05)$, and no significant differences in the distribution of alleles and genotypes were found between Hucul and AngloArabian breeds $(p>0.05)$.

Then, the association of the seven analyzed SNP with genomic 5-methyl-2'-deoxycytidine content was studied. The observed differences in the 5-methyl-2'deoxycytidine levels involving 18 genotype groups were not statistically significant (Fig. 4).

Since age-related loss in DNA methylation pattern may affect the stability of repetitive sequences, we decided to monitor TRF length and the level of pericentromeric heterochromatin during horse aging. We found developmentand age-associated telomere shortage $(n=60, r=-0.46$, $p=0.0001$ and $n=29, r=-0.69, p=0.001$, respectively) 
(Fig. 5a, b). A typical Southern blot result is presented (Fig. 5c).

Changes in pericentromeric heterochromatin were also evaluated during horse aging. A decrease in the size of Cbands was observed with increasing horse donor age during the juvenile-to-aged period ( $n=60, r=-0.3, p=0.02$ ) (Fig. 6a). After exclusion of young horses from the analysis, a very mild positive correlation was observed during the adult-to-aged period, $n=29, r=0.05$. The effect was not statistically significant, $p=0.8$ (Fig. 6b). A micrograph showing metaphase spread with C-band staining obtained from young and old horses is also included (Fig. 6c, d).

Finally, we asked for cell proliferative potential during horse aging. We used both mitotic index and AgNORs technique to monitor development- and age-related changes in cell proliferation. The AgNORs technique, monitoring the number and size of silver deposits (argyrophilic nucleolar proteins), is considered as a parameter of cell proliferation rate and transcriptional rDNA activity reflecting the physiological state of the cell (Derenzini et al. 2000; Wnuk et al. 2008). For the combined group, we found a statistically significant decrease in the size and number of silver deposits (argyrophilic nucleolar proteins) during the juvenile-to-aged period $(n=60) r=-0.34, p=0.008$ and $r=-0.38, p=0.003$, respectively (Fig. 7a, c). During the adult-to-aged period $(n=29)$, the observed effects were less evident (AgNOR size: $r=0.21, p=0.265$ and AgNOR number: $r=-0.1, p=0.6$ ) (Fig. 7b, d).

Also, mitotic index dropped during horse development and aging ( $n=60, r=-0.3, p=0.018$ and $n=29, r=-0.32$, $p=0.088$ ) (Fig. 7e, f). Moreover, we studied the relationships between mitotic index and the size and number of AgNORs. We found a positive correlation between mitotic index and AgNORs area $(r=0.33$, $p=0.009$ ) (Fig. 8a) and between mitotic index and number of AgNORs $(r=0.33, p=0.011)$ (Fig. 8c) during the juvenile-to-aged period $(n=60)$. Similar correlations were less apparent during the adult-toaged period $(n=29)(r=0.003, p=0.988$ and $r=0.25$, $p=0.187$, respectively) (Fig. $8 \mathrm{~b}, \mathrm{~d})$.

\section{Discussion}

The horse aging model has been already successfully used to reveal the mechanisms of immunosenescence, inflammaging, and genomic instability (Adams et al. 2008, 2009; Horohov et al. 2002; Wnuk et al. 2011).
Fig. 3 Methylation of $\mathrm{CpG}$ islands in the promoter of $I G F 2$ gene. DNA methylation analysis was performed with bisulfite sequencing (see "Materials and methods"). a For optimizing amplification conditions, ten primer pairs were used (see Table 1). The BSPCR products (1-10) in the expected range of size are shown. $\mathbf{b}$ The sequencing read of fragment spanning 720 bp of contig NC_009155 of chromosome ECA 12 (start: 30636212, stop: $3063 \overline{6} 931$ ) to be the predicted promoter region of equine IGF2 gene. Arrows show CpG sites selected for the analysis. c The fragment of sequencing read of amplification product of bisulfite converted DNA spanning three $\mathrm{CpG}$ sites in $I G F 2$ gene. Main cytosine peaks (blue) and accompanying small thymine peaks (red) are shown. d A summary of three $\mathrm{CpG}$ islands methylation status of $I G F 2$ gene within the total horse population examined is presented (lollipop diagram, filled beads indicate methylated $\mathrm{CpG}$ islands)

In the present study, we used equine blood lymphocytes to monitor development- and age-associated changes in global DNA methylation pattern and repetitive sequences. We showed a statistically significant decrease in global DNA methylation levels, telomere shortage, and loss of pericentromeric heterochromatin with increasing donor age during the juvenile-to-aged period, while similar but statistically insignificant tendencies were observed during the adult-to-aged period.

It is widely accepted that aging is associated with epigenetic modifications which may have implications for various age-related diseases. It is suggested that a hallmark of age-related epigenetic changes is both a global DNA hypomethylation and locus-specific hypermethylation (Wilson et al. 1987; Fuke et al. 2004; Agrawal et al. 2010; Johnson et al. 2012). A global decrease in DNA methylation with increasing age was repeatedly shown using different animal models and cell culture-based studies (Wilson et al. 1987; Fuke et al. 2004). Global DNA hypomethylation was seen in both replicative and premature peroxide-induced senescence cells (Zhang et al. 2008). The lifespan of MRC-5 cells can be shortened about $25 \%$ in vitro by experimentally induced hypomethylation (Fairweather et al. 1987), and immortal cells are considered to be resistant to epigenetic changes (Wilson and Jones 1983). Also, many clinical studies confirmed a correlation between DNA hypomethylation and donor age (Bollati et al. 2009). On the other hand, locus-specific DNA hypermethylation such as ribosomal DNA and promoters containing $\mathrm{CpG}$ islands with increasing age was reported (Oakes et al. 2003; So et al. 2006). For example, a hypermethylation of several genes ( $E R$, $M Y O D 1, I G F 2, N 33)$ was demonstrated to appear as a function of age in the human colon (Issa 2003). Our 


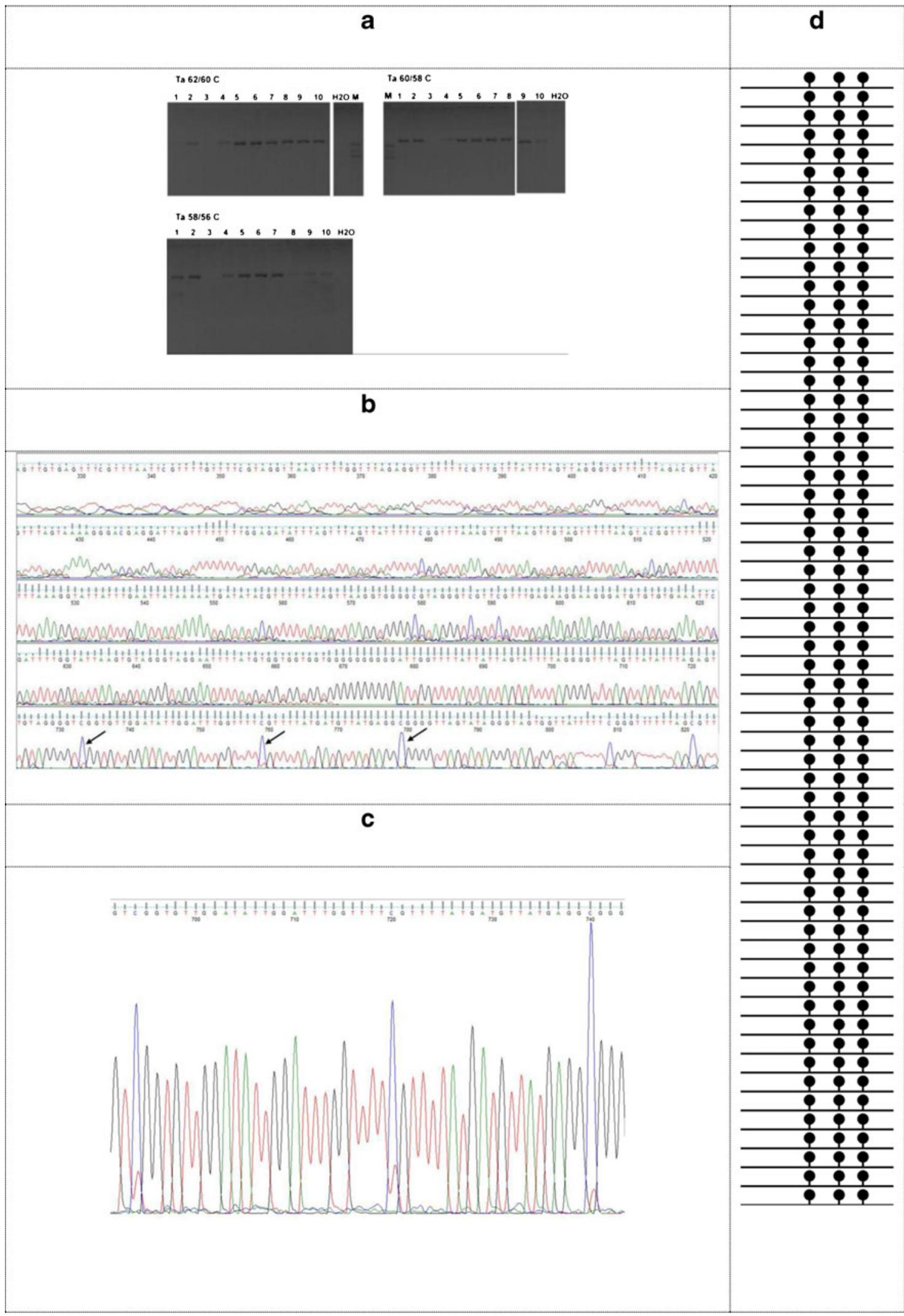


Table 4 The allele and genotype frequencies of seven analyzed polymorphisms (SNP) of equine DNA methyltransferase genes (DNMT1, DNMT3a, and DNMT3b). Genotype analysis was determined in 60 horses (see "Materials and methods"); $n$ represents the number of observed alleles or genotypes

\begin{tabular}{|c|c|c|c|c|c|c|}
\hline Gene & Region & Allele & & Genotype & & \\
\hline \multirow[t]{6}{*}{ DNMT1 } & Intron 2 & T: 0.442 & C: 0.558 & $\mathrm{~T} / \mathrm{T}: 0.183$ & C/T: 0.517 & $\mathrm{C} / \mathrm{C}: 0.3$ \\
\hline & & $n=53$ & $n=67$ & $n=11$ & $n=31$ & $n=18$ \\
\hline & Intron 21 & A: 0.95 & G: 0.05 & A/A: 0.9 & A/G: 0.1 & G/G: 0 \\
\hline & & $n=114$ & $n=6$ & $n=54$ & $n=6$ & $n=0$ \\
\hline & Intron 22 & A: 0.558 & G: 0.442 & A/A: 0.3 & A/G: 0.517 & G/G: 0.183 \\
\hline & & $n=67$ & $n=53$ & $n=18$ & $n=31$ & $n=11$ \\
\hline \multirow[t]{2}{*}{ DNMT3b } & Intron 13 & T: 0.325 & C: 0.675 & $\mathrm{~T} / \mathrm{T}: 0.2$ & $\mathrm{C} / \mathrm{T}: 0.25$ & $\mathrm{C} / \mathrm{C}: 0.55$ \\
\hline & & $n=39$ & $n=81$ & $n=12$ & $n=15$ & $n=33$ \\
\hline \multirow[t]{6}{*}{ DNMT3a } & Intron 3 & A: 0.667 & G: 0.333 & A/A: 0.433 & A/G: 0.467 & G/G: 0.1 \\
\hline & & $n=80$ & $n=40$ & $n=26$ & $n=28$ & $n=6$ \\
\hline & Intron 7 & A: 0.942 & G: 0.058 & A/A: 0.883 & A/G: 0.117 & G/G: 0 \\
\hline & & $n=113$ & $n=7$ & $n=53$ & $n=7$ & $n=0$ \\
\hline & Intron 17 & G: 0.942 & C: 0.058 & $\mathrm{G} / \mathrm{G}: 0.883$ & $\mathrm{G} / \mathrm{C}: 0.117$ & $\mathrm{C} / \mathrm{C}: 0$ \\
\hline & & $n=113$ & $n=7$ & $n=53$ & $n=7$ & $n=0$ \\
\hline
\end{tabular}

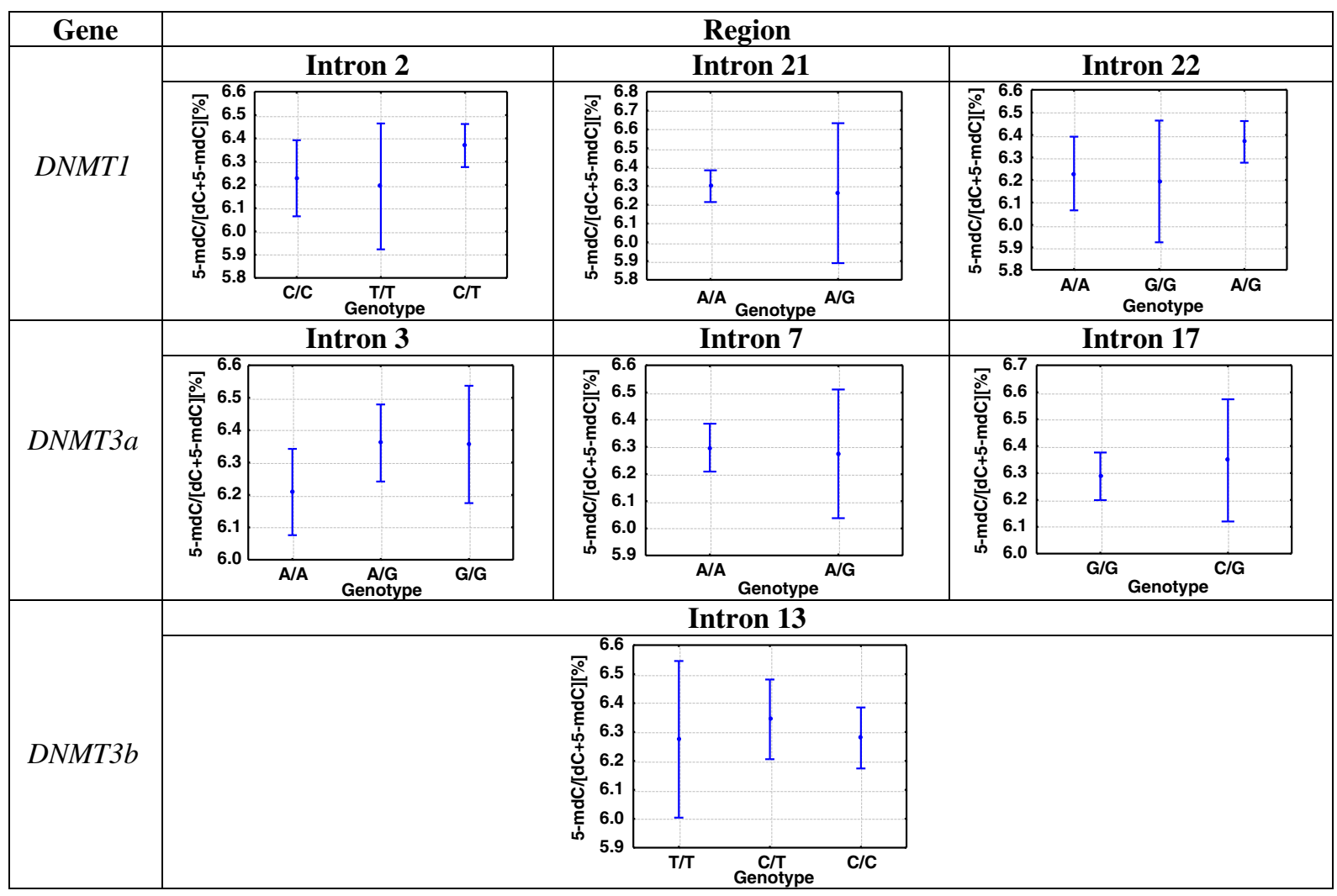

Fig. 4 The effect of seven analyzed SNP of equine DNA methyltransferase genes (DNMT1, DNMT3a, and DNMT3b) on global 5-methyl-2'-deoxycytidine level. Differences in genomic 5-methyl-2'-deoxycytidine content in 18 genotype groups from the combined horse group (Hucul and Anglo-Arabian breed) were assessed with ANOVA with post hoc testing using a Tukey's multiple comparison test 


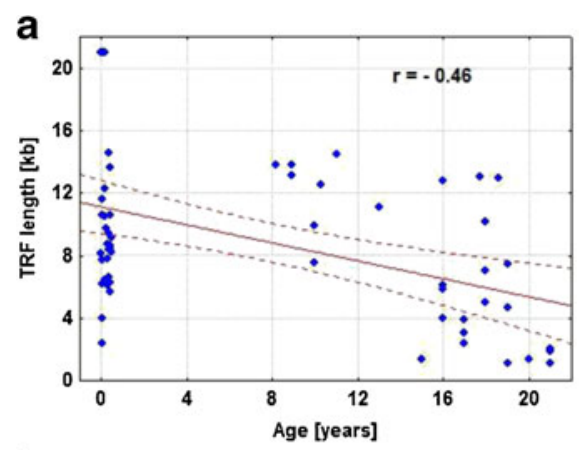

b

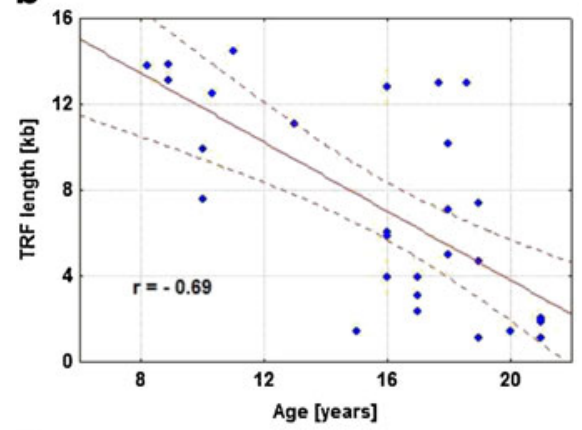

c

M C S1 S2 S3 S4 S5 S6 S7 S8 S9

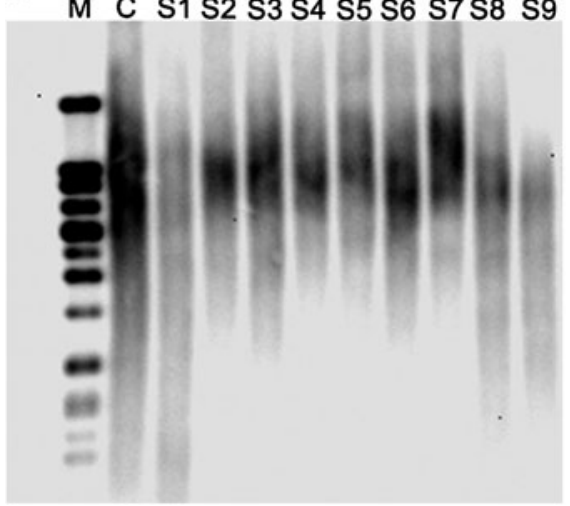

Fig. 5 Telomere shortage during juvenile-to-aged period (a) and adult-to-aged period (b). Telomere restriction fragment (TRF) length [kilobase] was measured using the TeloTAGGG telomere length assay kit (see "Materials and methods"). a, b A negative correlation between TRF length and horse donor age is presented. a $n=60, r=-0.46, p=0.0001$; b $n=29, r=-0.69, p=$ 0.001 . Results represent the mean from three independent experiments. Correlation analysis of the data was performed using a linear correlation (Pearson $r$ ) test. c Representative picture from Southern blot analysis is shown. Lanes: $M-$ DIG-molecular weight marker, 0.8-21.2 [kb], $C$ - control DNA, 7.6 \pm 0.4 [kb], S1-S7-DNA samples from young horses, $S 8-S 9-\mathrm{DNA}$ samples from old horses

analysis did not reveal any significant changes in $5.8 \mathrm{~S}$, $18 \mathrm{~S}$, and $28 \mathrm{~S}$ rDNA methylation with increasing horse age. We recorded a mild increase in rDNA methylation during the juvenile-to-aged period in the combined horse group, but the effect was not statistically significant. We also conducted analysis on methylation of $\mathrm{CpG}$ islands within the promoter of $I G F 2$ gene, the variability of which was found to be associated with human longevity (De Luca et al. 2001). Insulin-like growth factor 2 (IGF2) is a very important regulator of growth and development and $I G F 2$ gene is subjected to epigenetic modifications (Brandeis et al. 1993). Altered expression of the $I G F 2$ gene was implicated in the pathogenesis of neoplastic and non-neoplastic overgrowth conditions (Ward 1997). In our hands, the methylation of three selected $\mathrm{CpG}$ islands of promoter of equine IGF2 gene was comparable between young and old horses, suggesting that aging could not be considered as a factor modulating methylation status of selected $\mathrm{CpG}$ islands within equine $I G F 2$ gene.

Subsequently, we evaluated a hypothesis if genetic components such as SNP within DNA methyltransferase genes (DNMT1, DNMT3a, and DNMT3b) may account for observed changes in global DNA methylation levels with increasing age. We tested seven intronic polymorphisms of which six spanned large portions of DNMT1 and DNMT3a genes, assuming that they will be able to capture at least some part of genetic variation inside the genes and by the potential linkage with unknown functional polymorphism located in the same part of the gene allow for identification of regions responsible for changes in individual methylation profiles. Moreover, the number of polymorphisms located in noncoding regions of the genes has already been reported to be associated with resistance to diseases (Chun et al. 2009; Singal et al. 2005; Zhou et al. 2010) or different phenotype occurrence (Millar et al. 2010; Fujihara et al. 2009). Among the 18 genotypes analyzed, we were unable to record any statistically significant differences in 5-methyl-2'-deoxycytidine levels, which suggested that age-related changes in global DNA methylation content are rather a function of time, and not a genetic component.

Epigenetics may also provide interesting evidence for some programmatic features of aging originating in development (de Magalhaes 2012). Since changes in DNA methylation pattern in differentiation and developmental genes (e.g., homeobox genes) were revealed during aging of human stromal mesenchymal cells (Bork et al. 2010), epigenetically regulated developmental processes can be considered as contributors to aging. Moreover, specific age-associated DNA methylation changes in human dermal fibroblasts were 
Fig. $6 \mathrm{Changes}$ in pericentromeric heterochromatin level during juvenileto-aged period (a) and adultto-aged period (b).

Pericentromeric heterochromatin was assessed as a size of C-bands. a $n=60, r=$ $-0.3, p=0.02$; b $n=29, r=$ $0.05, p=0.8$. Results represent the mean from three independent experiments. Correlation analysis of the data was performed using a linear correlation (Pearson $r$ ) test. c, d Representative micrographs of metaphase spreads obtained from young (c) and old (d) animals are shown
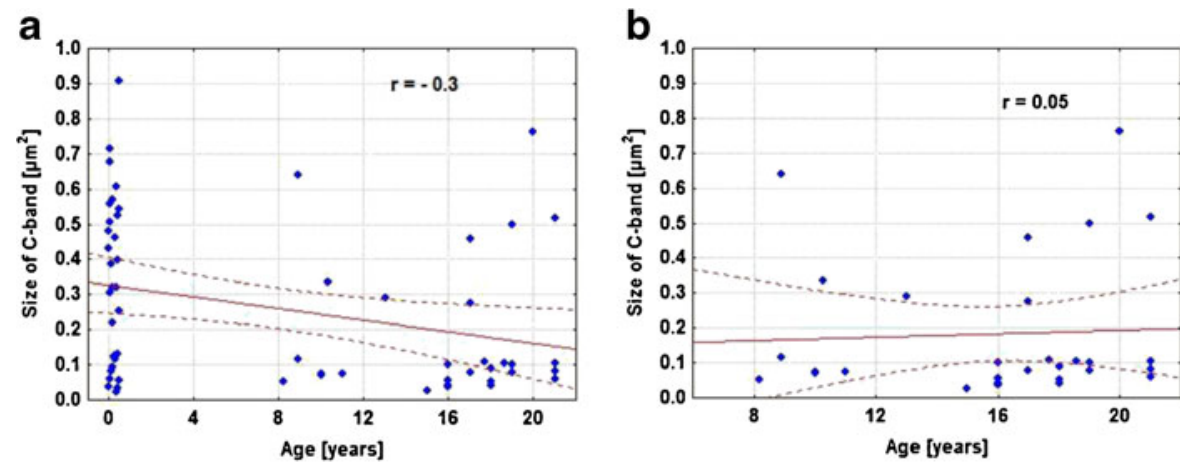

C

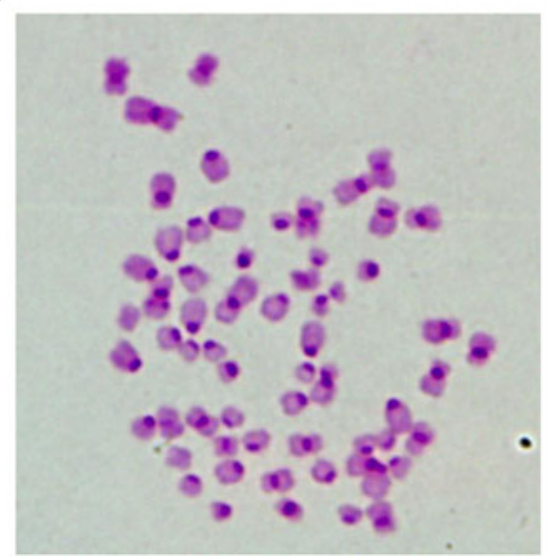

d

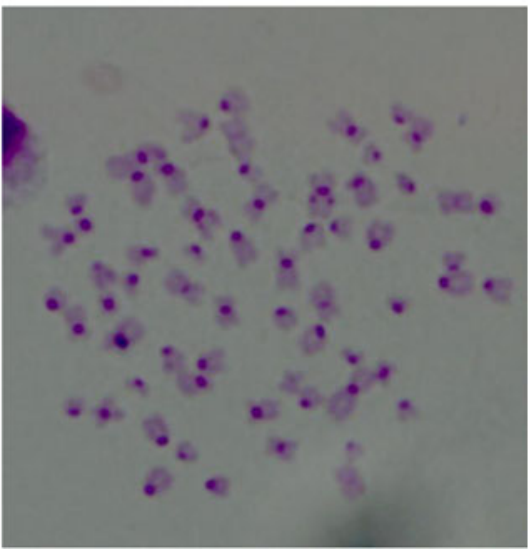

observed and aging was proposed to be a coordinated developmental mechanism that seems to be regulated in a cell-type-specific manner (Koch et al. 2011). It was also reported that in different mouse tissues (muscle, brain, liver), DNA methylation status consistently moved toward development/maturation throughout lifespan, and the tissue-dependent epigenetic or transcriptional status underlies the methylation changes (Takasugi 2011). Taken together, some aging processes seem to be an extension of development and begin prior to adulthood (de Magalhaes and Church 2005; de Magalhaes and Sandberg 2005). Since we observed a statistically significant loss in global DNA methylation during horse juvenile-to-aged period compared to similar but statistically insignificant tendency during adultto-aged period, it may be suggested that also in horses, developmental processes which are regulated by epigenetic modifications may affect aging. Further studies are needed to confirm such hypothesis.

It is widely accepted that changes in DNA methylation may contribute to genomic instability. A decrease in global DNA methylation in cell lines from immunodeficiency syndrome patients may lead to chromosomal loss, gain, or rearrangement (Tuck-Muller et al. 2000). DNA hypomethylation in male germ cells may also account for meiotic abnormalities (Bourc'his and Bestor 2004). We were also interested if changes in DNA methylation during horse development and aging may affect stability of repetitive sequences. Indeed, telomere shortage and loss of pericentromeric heterochromatin were revealed with increasing horse donor age. It was already reported that telomeres may account to aging of equine cells both in vivo and in vitro, and telomere shortage was correlated with immunosenescence parameters (Argyle et al. 2003; Katepalli et al. 2008). Dysfunctional telomeres are strongly associated with chromosomal instability in mammalian cells which may lead to both cancer and aging (Mathieu et al. 2004; Bailey and Murnane 2006). Our data are in agreement with previous findings that epigenetically regulated chromatin structure may affect the genomic integrity of telomeric region and telomere length maintenance (Kim et al. 2012; Blasco 2007). Deregulation of epigenetic modifications may stimulate telomeric region disintegration, and on the other hand, telomere shortage in the absence of telomerase may promote a plethora of epigenetic changes such as 
increased histone acetylation, decreased histone methylation, and subtelomeric DNA methylation (Blasco 2007; Grewal and Moazed 2003). Moreover, epigenetic changes contributing to global heterochromatin loss may underlie the various cellular processes associated with aging (Tsurumi and Li 2012).

A decrease in mitogen-induced cell proliferative potential, a key element of the phenotype of senescent cells (Pawelec 1995), is also characteristic for horse lymphocytes from the old population (Horohov et al. 1999,
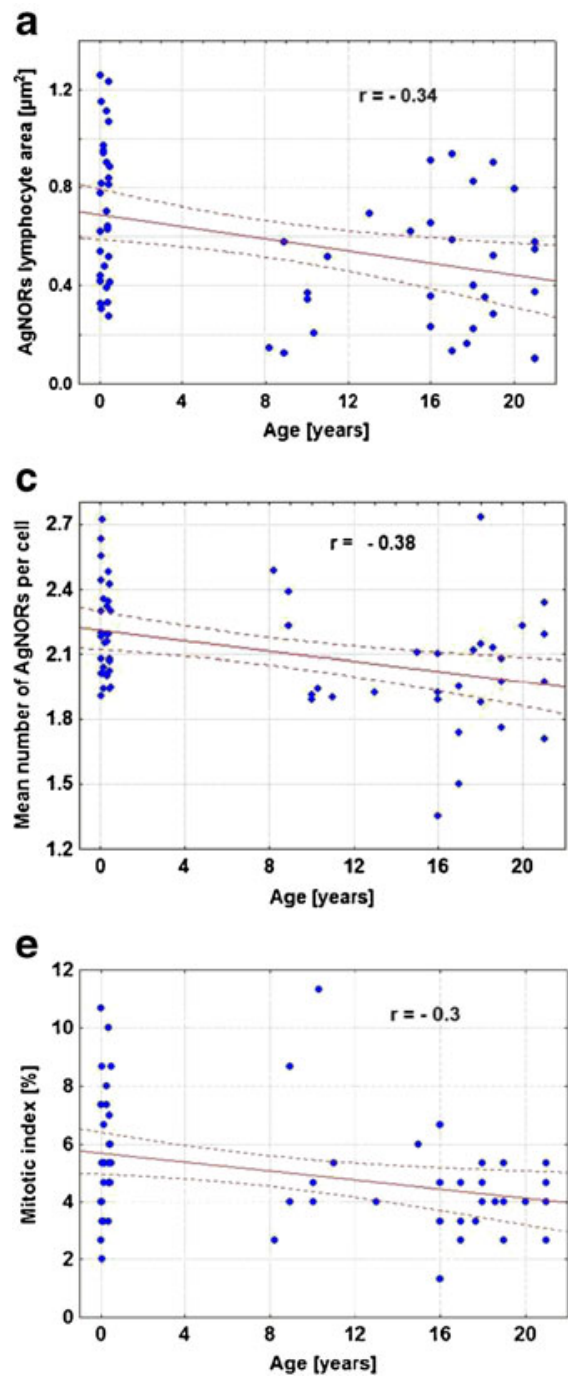

Fig. 7 Decline in cell proliferation during juvenile-to-aged period $(\mathbf{a}, \mathbf{c}, \mathbf{e})$ and adult-to-aged period $(\mathbf{b}, \mathbf{d}, \mathbf{f})$. a-d AgNOR assay. The analysis of interphase AgNORs was conducted with the morphometric $(\mathbf{a}, \mathbf{b})$ and counting $(\mathbf{c}, \mathbf{d})$ method according to the guidelines of the Committee on AgNOR Quantification. Correlation analysis within the combined horse group (Hucul
2002). We were also able to show a diminution in cell proliferation as estimated with mitotic index and silver staining of nucleolar organizer regions (AgNOR, nucleolar argyrophilic proteins). The number and size of silver deposits were decreased with increasing horse age. With AgNORs method, nucleoli in interphase nuclei can be visualized and are considered as a parameter of cell proliferation rate and a significant marker in tumor pathology, since increased AgNORs protein expression was shown in cancer cells compared to noncancer cells
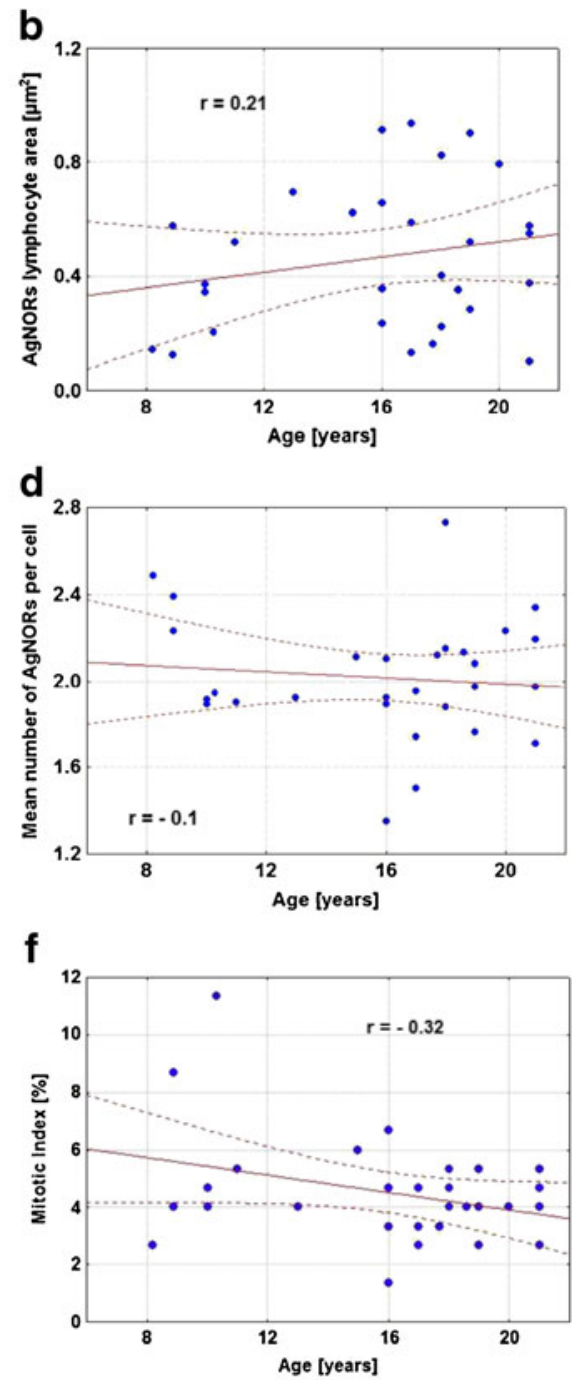

and Anglo-Arabian breed) is shown. The number (c, d) of argyrophilic nucleolar proteins is decreased during horse development and aging. $\mathbf{c} n=60, r=-0.38, p=0.003 ; \mathbf{d} n=29, r=-0.1$, $p=0.6$. e, f Mitotic index (metaphase spreads per 100 cells) is diminished during horse development and aging. e $n=60, r=$ $-0.3, p=0.018 ; \mathbf{f} n=29, r=-0.32, p=0.088$ 

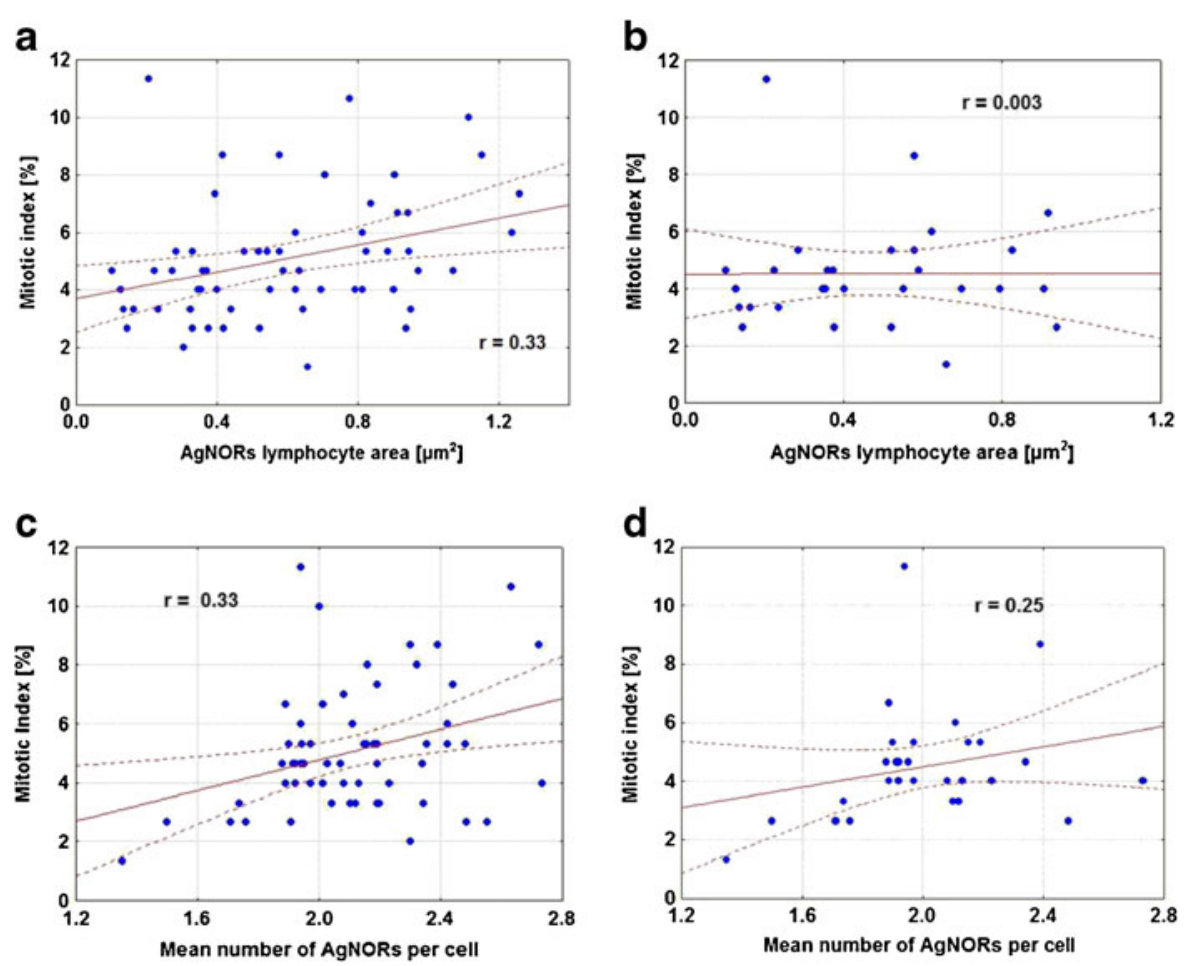

Fig. 8 A positive correlation between mitotic index and size of AgNORs is shown (a juvenile-to-aged period; b adult-to-aged period). a $n=60, r=0.33, p=0.009$; b $n=29$, $r=0.003, p=0.988$. A positive correlation between mitotic index and the number of AgNORs is presented (c

(Derenzini et al. 2000). AgNORs expression, reflecting also transcriptional rDNA activity, is associated with physiological state of the cell, especially stress conditions (Wnuk et al. 2008). Oxidants may contribute to downregulation of rRNA synthesis by c-Jun $\mathrm{N}$ terminal kinasemediated inactivation of the transcription factor TIF-IA (Mayer et al. 2005), and in turn, such inactivation may lead to nucleolar disruption, cell cycle arrest, and p53-mediated apoptosis (Yuan et al. 2005). Our data suggested that aging similar to oxidative stress can be considered as a factor modulating transcriptional rDNA activity. Moreover, we have already shown that lymphocytes of old horses are more prone to apoptosis than young ones (Wnuk et al. 2011).

In conclusion, our data show an association between global DNA hypomethylation and changes in repetitive sequences with increasing horse donor age, especially during the juvenile-to-aged period. Moreover, a decrease in 5-methyl-2'-deoxycytidine level and loss of pericentromeric heterochromatin

juvenile-to-aged period; d adult-to-aged period). c $n=60$, $r=0.33, p=0.011$; d $n=29, r=0.25, p=0.187$. Results represent the mean from three independent experiments. Correlation analysis of the data was performed using a linear correlation (Pearson $r$ ) test

originating during development may contribute to the already observed genomic instability during aging in horse (Wnuk et al. 2011). Indeed, we have already observed that the levels of positive TUNEL cells (both apoptotic and with DNA fragmentation), oxidative DNA damage (8-oxoG immunostaining), sister chromatid exchange, and bleomycin-induced chromatid breaks were significantly increased in the combined horse old group compared to the combined horse adult group (Wnuk et al. 2011). Such scenario seems probable since DNA hypomethylation was shown to stimulate chromosomal translocations and/or mutations and to promote both cancer and aging (Richardson 2003).

Acknowledgments The authors would like to thank Dr. João Pedro de Magalhães (Integrative Genomics of Ageing Group, Institute of Integrative Biology, University of Liverpool, UK) for providing valuable comments on the manuscript. This work was supported by Grant No. N N311 068937 from the State Committee for Scientific Research of Poland. M.W. is a recipient of the fellowship of the Foundation for Polish Science. 
Open Access This article is distributed under the terms of the Creative Commons Attribution License which permits any use, distribution, and reproduction in any medium, provided the original author(s) and the source are credited.

\section{References}

Adams AA, Breathnach CC, Katepalli MP, Kohler K, Horohov DW (2008) Advanced age in horses affects divisional history of $\mathrm{T}$ cells and inflammatory cytokine production. Mech Ageing Dev 129(11):656-664

Adams AA, Katepalli MP, Kohler K, Reedy SE, Stilz JP, Vick MM, Fitzgerald BP, Lawrence LM, Horohov DW (2009) Effect of body condition, body weight and adiposity on inflammatory cytokine responses in old horses. Vet Immunol Immunopathol 127(3-4):286-294

Agrawal A, Tay J, Yang GE, Agrawal S, Gupta S (2010) Ageassociated epigenetic modifications in human DNA increase its immunogenicity. Aging (Albany NY) 2(2):93-100

Argyle D, Ellsmore V, Gault EA, Munro AF, Nasir L (2003) Equine telomeres and telomerase in cellular immortalisation and ageing. Mech Ageing Dev 124(6):759-764

Aubele M, Biesterfeld S, Derenzini M, Hufnagl P, Martin H, Ofner D, Ploton D, Ruschoff J (1994) Guidelines of AgNOR quantitation. Committee on AgNOR Quantitation within the European Society of Pathology. Zentralbl Pathol 140(1):107-108

Bailey SM, Murnane JP (2006) Telomeres, chromosome instability and cancer. Nucleic Acids Res 34(8):2408-2417

Bestor T, Laudano A, Mattaliano R, Ingram V (1988) Cloning and sequencing of a cDNA encoding DNA methyltransferase of mouse cells. The carboxyl-terminal domain of the mammalian enzymes is related to bacterial restriction methyltransferases. J Mol Biol 203(4):971-983

Blasco MA (2007) The epigenetic regulation of mammalian telomeres. Nat Rev Genet 8(4):299-309

Bollati V, Schwartz J, Wright R, Litonjua A, Tarantini L, Suh H, Sparrow D, Vokonas P, Baccarelli A (2009) Decline in genomic DNA methylation through aging in a cohort of elderly subjects. Mech Ageing Dev 130(4):234-239

Bork S, Pfister S, Witt H, Horn P, Korn B, Ho AD, Wagner W (2010) DNA methylation pattern changes upon long-term culture and aging of human mesenchymal stromal cells. Aging Cell 9(1):54-63

Bornman DM, Mathew S, Alsruhe J, Herman JG, Gabrielson E (2001) Methylation of the E-cadherin gene in bladder neoplasia and in normal urothelial epithelium from elderly individuals. Am J Pathol 159(3):831-835

Bourc'his D, Bestor TH (2004) Meiotic catastrophe and retrotransposon reactivation in male germ cells lacking Dnmt3L. Nature 431(7004):96-99

Brandeis M, Kafri T, Ariel M, Chaillet JR, McCarrey J, Razin A, Cedar H (1993) The ontogeny of allele-specific methylation associated with imprinted genes in the mouse. EMBO J 12(9):3669-3677

Carr IM, Valleley EM, Cordery SF, Markham AF, Bonthron DT (2007) Sequence analysis and editing for bisulphite genomic sequencing projects. Nucleic Acids Res 35(10):e79

Cartharius K, Frech K, Grote K, Klocke B, Haltmeier M, Klingenhoff A, Frisch M, Bayerlein M, Werner T (2005)
MatInspector and beyond: Promoter analysis based on transcription factor binding sites. Bioinformatics 21(13):29332942

Choi EK, Uyeno S, Nishida N, Okumoto T, Fujimura S, Aoki Y, Nata M, Sagisaka K, Fukuda Y, Nakao K, Yoshimoto T, Kim YS, Ono T (1996) Alterations of c-fos gene methylation in the processes of aging and tumorigenesis in human liver. Mutat Res 354(1):123-128

Chun JY, Bae JS, Park TJ, Kim JY, Park BL, Cheong HS, Lee HS, Kim YJ, Shin HD (2009) Putative association of DNA methyltransferase 1 (DNMT1) polymorphisms with clearance of HBV infection. BMB Rep 42(12):834-839

Das PM, Singal R (2004) DNA methylation and cancer. J Clin Oncol 22(22):4632-4642

De Luca M, Rose G, Bonafe M, Garasto S, Greco V, Weir BS, Franceschi C, De Benedictis G (2001) Sex-specific longevity associations defined by Tyrosine Hydroxylase-InsulinInsulin Growth Factor 2 haplotypes on the 11p15.5 chromosomal region. Exp Gerontol 36(10):1663-1671

de Magalhaes JP (2012) Programmatic features of aging originating in development: Aging mechanisms beyond molecular damage? FASEB J 26(12):4821-4826

de Magalhaes JP, Church GM (2005) Genomes optimize reproduction: aging as a consequence of the developmental program. Physiology (Bethesda) 20:252-259

de Magalhaes JP, Sandberg A (2005) Cognitive aging as an extension of brain development: A model linking learning, brain plasticity, and neurodegeneration. Mech Ageing Dev 126(10):1026-1033

Derenzini M, Trere D (1991) Standardization of interphase AgNOR measurement by means of an automated image analysis system using lymphocytes as an internal control. J Pathol 165(4):337-342

Derenzini M, Trere D, Pession A, Govoni M, Sirri V, Chieco P (2000) Nucleolar size indicates the rapidity of cell proliferation in cancer tissues. J Pathol 191(2):181-186

Fairweather DS, Fox M, Margison GP (1987) The in vitro lifespan of MRC-5 cells is shortened by 5-azacytidineinduced demethylation. Exp Cell Res 168(1):153-159

Fujihara J, Fujii Y, Agusa T, Kunito T, Yasuda T, Moritani T, Takeshita H (2009) Ethnic differences in five intronic polymorphisms associated with arsenic metabolism within human arsenic (+3 oxidation state) methyltransferase (AS3MT) gene. Toxicol Appl Pharmacol 234(1):41-46

Fuke C, Shimabukuro M, Petronis A, Sugimoto J, Oda T, Miura K, Miyazaki T, Ogura C, Okazaki Y, Jinno Y (2004) Age related changes in 5-methylcytosine content in human peripheral leukocytes and placentas: An HPLC-based study. Ann Hum Genet 68(Pt 3):196-204

Grewal SI, Moazed D (2003) Heterochromatin and epigenetic control of gene expression. Science 301(5634):798-802

Horohov DW, Dimock A, Guirnalda P, Folsom RW, McKeever KH, Malinowski K (1999) Effect of exercise on the immune response of young and old horses. Am J Vet Res 60(5):643-647

Horohov DW, Kydd JH, Hannant D (2002) The effect of aging on T cell responses in the horse. Dev Comp Immunol 26(1):121-128

Howell WM, Black DA (1980) Controlled silver-staining of nucleolus organizer regions with a protective colloidal developer: A 1-step method. Experientia 36(8):1014-1015

Issa JP (2003) Age-related epigenetic changes and the immune system. Clin Immunol 109(1):103-108 
Jenuwein T, Allis CD (2001) Translating the histone code. Science 293(5532):1074-1080

Johnson AA, Akman K, Calimport SR, Wuttke D, Stolzing A, de Magalhaes JP (2012) The role of DNA methylation in aging, rejuvenation, and age-related disease. Rejuvenation Res 15(5):483-494

Jones PA, Baylin SB (2002) The fundamental role of epigenetic events in cancer. Nat Rev Genet 3(6):415-428

Katepalli MP, Adams AA, Lear TL, Horohov DW (2008) The effect of age and telomere length on immune function in the horse. Dev Comp Immunol 32(12):1409-1415

Kim S, Parks CG, Xu Z, Carswell G, DeRoo LA, Sandler DP, Taylor JA (2012) Association between genetic variants in DNA and histone methylation and telomere length. PLoS One 7(7):e40504

Klein G (2005) Epigenetics: Surveillance team against cancer. Nature 434(7030):150

Koch CM, Suschek CV, Lin Q, Bork S, Goergens M, Joussen S, Pallua N, Ho AD, Zenke M, Wagner W (2011) Specific age-associated DNA methylation changes in human dermal fibroblasts. PLoS One 6(2):e16679

Mathieu N, Pirzio L, Freulet-Marriere MA, Desmaze C, Sabatier L (2004) Telomeres and chromosomal instability. Cell Mol Life Sci 61(6):641-656

Mayer C, Bierhoff H, Grummt I (2005) The nucleolus as a stress sensor: JNK2 inactivates the transcription factor TIF-IA and down-regulates rRNA synthesis. Genes Dev 19(8):933-941

Mays-Hoopes L, Chao W, Butcher HC, Huang RC (1986) Decreased methylation of the major mouse long interspersed repeated DNA during aging and in myeloma cells. Dev Genet 7(2):65-73

McFarlane D, Sellon DC, Gibbs SA (2001) Age-related quantitative alterations in lymphocyte subsets and immunoglobulin isotypes in healthy horses. Am J Vet Res 62(9):14131417

Millar DS, Horan M, Chuzhanova NA, Cooper DN (2010) Characterisation of a functional intronic polymorphism in the human growth hormone (GH1) gene. Hum Genomics 4(5):289-301

Nicholas KB, Nicholas HB, Deerfield DW (1997) GeneDoc: Analysis and visualization of genetic variation. Embnet News 4:1-4

Oakes CC, Smiraglia DJ, Plass C, Trasler JM, Robaire B (2003) Aging results in hypermethylation of ribosomal DNA in sperm and liver of male rats. Proc Natl Acad Sci U S A 100(4):17751780

Okano M, Xie S, Li E (1998) Cloning and characterization of a family of novel mammalian DNA (cytosine-5) methyltransferases. Nat Genet 19(3):219-220

Paradis MR (2002) Demographics of health and disease in the geriatric horse. Vet Clin North Am Equine Pract 18(3):391-401

Pawelec G (1995) Molecular and cell biological studies of ageing and their application to considerations of T lymphocyte immunosenescence. Mech Ageing Dev 79(1):1-32

Rath PC, Kanungo MS (1989) Methylation of repetitive DNA sequences in the brain during aging of the rat. FEBS Lett 244(1):193-198

Richardson B (2003) Impact of aging on DNA methylation. Ageing Res Rev 2(3):245-261
Robertson KD (2002) DNA methylation and chromatin - unraveling the tangled web. Oncogene 21(35):5361-5379

Romanov GA, Vanyushin BF (1981) Methylation of reiterated sequences in mammalian DNAs. Effects of the tissue type, age, malignancy and hormonal induction. Biochim Biophys Acta 653(2):204-218

Schmiady H, Munke M, Sperling K (1979) Ag-staining of nucleolus organizer regions on human prematurely condensed chromosomes from cells with different ribosomal RNA gene activity. Exp Cell Res 121(2):425-428

Singal R, Das PM, Manoharan M, Reis IM, Schlesselman JJ (2005) Polymorphisms in the DNA methyltransferase $3 \mathrm{~b}$ gene and prostate cancer risk. Oncol Rep 14(2):569-573

So K, Tamura G, Honda T, Homma N, Waki T, Togawa N, Nishizuka S, Motoyama T (2006) Multiple tumor suppressor genes are increasingly methylated with age in nonneoplastic gastric epithelia. Cancer Sci 97(11):1155-1158

Sumner AT (1972) A simple technique for demonstrating centromeric heterochromatin. Exp Cell Res 75(1):304-306

Takasugi M (2011) Progressive age-dependent DNA methylation changes start before adulthood in mouse tissues. Mech Ageing Dev 132(1-2):65-71

Takatsu M, Uyeno S, Komura J, Watanabe M, Ono T (1999) Age-dependent alterations in mRNA level and promoter methylation of collagen alpha1(I) gene in human periodontal ligament. Mech Ageing Dev 110(1-2):37-48

Tsurumi A, Li WX (2012) Global heterochromatin loss: A unifying theory of aging? Epigenetics 7(7):680-688

Tuck-Muller CM, Narayan A, Tsien F, Smeets DF, Sawyer J, Fiala ES, Sohn OS, Ehrlich M (2000) DNA hypomethylation and unusual chromosome instability in cell lines from ICF syndrome patients. Cytogenet Cell Genet 89(1-2):121-128

Ward A (1997) Beck-Wiedemann syndrome and Wilms' tumour. Mol Hum Reprod 3(2):157-168

Wilson VL, Jones PA (1983) DNA methylation decreases in aging but not in immortal cells. Science 220(4601):1055-1057

Wilson VL, Smith RA, Ma S, Cutler RG (1987) Genomic 5methyldeoxycytidine decreases with age. J Biol Chem 262(21):9948-9951

Wnuk M, Bugno-Poniewierska M, Lewinska A, Oklejewicz B, Zabek T, Bartosz G, Slota E (2011) Age-related changes in genomic stability of horses. Mech Ageing Dev 132(5):257268

Wnuk M, Lewinska A, Bugno M, Bartosz G, Slota E (2008) Oxidant-induced decrease of the expression of nucleolar organizer regions in pig lymphocytes can be useful for monitoring the cellular effects of oxidative stress. Mutat Res 653(1-2):124-129

Yuan X, Zhou Y, Casanova E, Chai M, Kiss E, Grone HJ, Schutz G, Grummt I (2005) Genetic inactivation of the transcription factor TIF-IA leads to nucleolar disruption, cell cycle arrest, and p53-mediated apoptosis. Mol Cell 19(1):77-87

Zhang W, Ji W, Yang J, Yang L, Chen W, Zhuang Z (2008) Comparison of global DNA methylation profiles in replicative versus premature senescence. Life Sci 83(13-14):475-480

Zhang Z, Deng C, Lu Q, Richardson B (2002) Age-dependent DNA methylation changes in the ITGAL (CD11a) promoter. Mech Ageing Dev 123(9):1257-1268

Zhou J, Nagarkatti PS, Zhong Y, Creek K, Zhang J, Nagarkatti M (2010) Unique SNP in CD44 intron 1 and its role in breast cancer development. Anticancer Res 30(4):1263-1272 